\title{
PENGEMBANGAN INSTRUMEN ASESMEN KOMPETENSI MINIMUM (AKM) LITERASI MEMBACA LEVEL 2 UNTUK SISWA KELAS 4 SD
}

\author{
D.M. Andikayana ${ }^{1}$, N. Dantes ${ }^{2}$, I.W. Kertih ${ }^{3}$ \\ ${ }^{123}$ Program Studi Pendidikan Dasar \\ Universitas Pendidikan Ganesha \\ Singaraja, Indonesia \\ e-mail: andikayana@undiksha.ac.id ${ }^{1}$, dantes@undiksha.ac.id ${ }^{2}$, \\ watan.kertih@undiksha.ac.id ${ }^{3}$
}

\begin{abstract}
Abstrak
Penelitian ini bertujuan untuk: 1) mendeskripsikan unsur-unsur setiap langkah pengembangan instrumen AKM literasi membaca level 2; 2) mengetahui dan mendeskripsikan validitas isi pengembangan instrumen AKM literasi membaca level 2; 3) mengetahui dan mendeskripsikan validitas empiris pengembangan instrumen AKM literasi membaca level 2; 4) mengetahui dan mendeskripsikan reliabilitas empiris pengembangan instrumen AKM literasi membaca level 2 untuk siswa kelas 4 SD. Jenis penelitian ini merupakan penelitian pengembangan Research and Development $(\mathrm{R} \& \mathrm{D})$ berdasarkan model pengembangan yang dikemukakan oleh Mardapi yang terdiri dari 7 langkah. Data yang dikumpulkan merupakan data kemampuan literasi membaca siswa yang diperoleh melalui ujicoba soal instrumen AKM literasi membaca level 2 yang dikhususkan untuk siswa kelas 4 SD. Data validitas isi, validitas empiris, dan reliabilitas yang telah dikumpulkan dianalisis menggunakan rumus Gregory, Product Moment, dan Alpha Cronbach. Hasil penelitian menunjukkan bahwa: 1) untuk instrumen AKM literasi membaca level 2, berdasarkan uji para ahli ditemukan nilai $C V=1$ termasuk dalam kategori validitas isi sangat tinggi. 2) Untuk uji validitas empiris baik subyek secara terbatas ataupun yang lebih luas, seluruh 30 butir soal memperoleh hasil nilai $r_{\text {hitung }}>r_{\text {tabel }}$. 3) Untuk uji reliabilitas dari instrumen AKM literasi membaca level 2 ini ditemukan nilai perhitungan reliabilitas dengan Alpha Cronbach sebesar 0.971 yang berada pada kriteria $0,80 \leq 1,00$ dengan kategori reliabilitas sangat tinggi. Berdasarkan hasil analisis data, disimpulkan bahwa penelitian ini menghasilkan instrumen AKM literasi membaca level 2 yang valid dan reliabel.
\end{abstract}

Kata kunci: Asesmen Kompetensi Minimum; Kemampuan Literasi Membaca; Pengembangan Instrumen

\begin{abstract}
This research is aimed to: 1) describe the elements of each step of developing a AKM instrument for reading literacy level 2; 2) find out and describe the content validity of the development of the AKM instrument reading literacy level 2; 3) find out and describe the empirical validity of the development of the AKM instrument for reading literacy level 2; 4) find out and describe the empirical reliability of the development of the AKM instrument for reading literacy level 2 for 4th grade elementary school students. This type of research is a research and development research and development (R\&D) based on the development model proposed by Mardapi which consists of 7 steps. The data collected is data on students' reading literacy skills obtained through testing the AKM reading literacy level 2 instrument which is specifically for 4th grade elementary school students. Content validity, empirical validity, and reliability data that have been collected were analyzed using the Gregory, Product Moment, and Cronbach's Alpha formulas. The results showed that: 1) for the AKM reading literacy level 2 instrument, based on judges tests, it was found that the $C V=1$ value was included in the very high content validity category. 2) To test the empirical validity of both limited and broader subjects, all 30 items obtained the results of the value of rcount $>$ rtable. 3) For the reliability test of the AKM literacy reading level 2 instrument, it was found that the reliability calculation value with Cronbach's Alpha was 0.971 which was in the criteria of $0.80<1.00$
\end{abstract}


with a very high reliability category. From those results, it can be concluded that this research produces valid and reliable AKM reading literacy level 2 instrument.

Keywords: Minimum Competency Assessment; Reading Literacy Ability; Instrument Development

\section{PENDAHULUAN}

Kedudukan bahasa tidak dapat lepas dari dunia pendidikan, karena dalam proses belajar mengajar sangat membutuhkan penggunaan bahasa. Bahasa diperlukan bukan cuma untuk membina keterampilan berkomunikasi, melainkan juga untuk kepentingan penguasaan kemampuan ilmu pengetahuan. Lewat bahasalah manusia belajar berbagai macam ilmu pengetahuan di dunia ini. Oleh sebab itu, sudah sepatutnya pembelajaran bahasa di sekolah dilaksanakan dengan sebaik-baiknya, sebab bahasa merupakan cerminan pribadi, karakter, bahkan pendidikan seseorang (Harlina \& Wardarita, 2020).

Era saat ini yang berada pada era revolusi industri 4.0 sangat begitu pesat mengalami perkembangan dalam bidang ilmu pengetahuan serta teknologi, masyarakat terus berupaya untuk meningkatkan kemampuannya di dalam dunia pendidikan. Pendidikan merupakan bentuk dari suatu kemajuan. Masyarakat yang maju ditunjukkan dengan majunya zona pendidikan yang berkualitas. Pendidikan yang bermutu tersebut ditandai salah satunya dengan sumber daya masyarakatnya yang literat (Indriyani et al., 2019).

Kemampuan literasi merupakan indikator penting untuk meningkatkan prestasi generasi muda dalam menggapai kesuksesannya. Penanaman literasi sejak dini harus dilakukan sebab hal tersebut mampu menjadi modal utama dalam mewujudkan bangsa yang cerdas dan berbudaya (Lamada et al., 2019). Berkaitan dengan hal diatas, Indonesia yang sudah pernah mengikuti Progress in International Reading Literacy Study (PIRLS) pada tahun 2011 yang diterbitkan oleh National Center Education Statistics (2013) memperoleh hasil yang tidak memuaskan, Indonesia sendiri berada pada urutan ke 41 dari 45 negara yang mengikuti PIRLS. Permasalahan serupa yang berlanjut dihadapi Indonesia saat ini menurut Tim Tentor Anak Bangsa (2020) ialah rendahnya penguasaan literasi yang dibuktikan melalui survei Programme for International Student Assessment (PISA) tahun 2018 yang diterbitakan oleh OECD pada tahun 2019. Hal tersebut ditunjukan pada gambar berikut

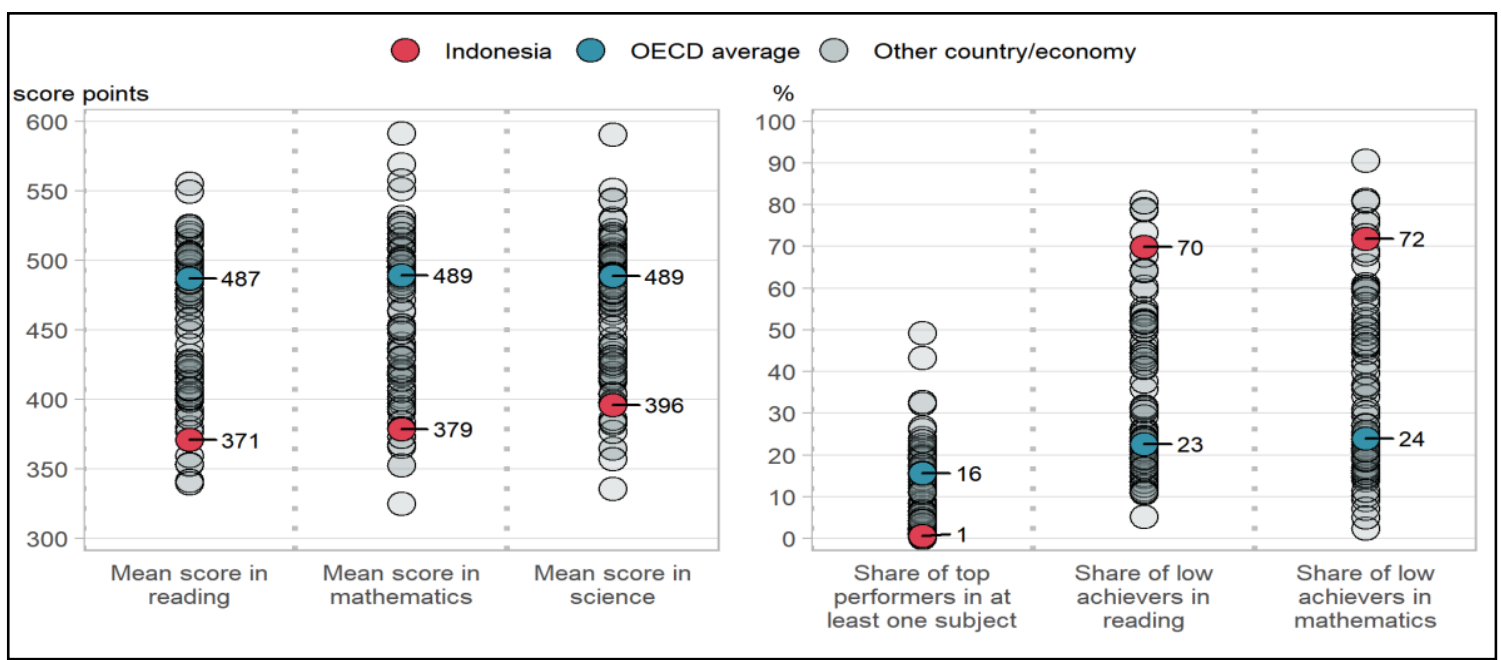

Gambar 1. Gambaran kinerja Indonesia dalam membaca, matematika, dan sains 
Hasil survei pada gambar diatas menunjukkan posisi Indonesia pada kategori membaca, matematika, dan sains terletak di urutan 6 negara terakhir dari 78 negara yang mengikuti PISA tahun 2018. Hasil studi PISA 2018 yang dirilis oleh OECD menunjukkan bahwa dalam membaca kemampuan siswa Indonesia, meraih skor rata-rata yakni 371 , dengan rata-rata skor OECD yakni 487. Kemudian untuk skor rata-rata matematika memperoleh 379 poin dengan skor rata-rata OECD 489. Selanjutnya untuk sains, skor rata-rata mencapai 396 dengan skor rata-rata perolehan OECD yakni 489. Perhitungan PISA yang dilakukan oleh OECD ini melibatkan 399 satuan pendidikan dengan 12.098 peserta didik. Data yang ditunjukkan oleh OECD tersebut dapat dimaknai bahwa: 1) Indonesia berada pada kategori lemah performa, 2) kemampuan literasi membaca, matematika dan sains rendah, 3) perolehan skor membaca, matematika dan sains rendah karena berada dibawah rata-rata. 4) tidak adanya peningkatan yang signifikan sejak perolehan PISA 2011 yang lalu, 5) banyaknya temuan bahwa siswa perempuan lebih baik dari siswa laki-laki dalam semua bidang di PISA, dan 6) perlunya perubahan paradigma pendidikan di Indonesia agar mampu meningkatkan pemerataan mutu dan kualitas pendidikan terutama dalam bidang membaca, matematika dan sains yang sangat berperan penting untuk menyokong berbagai keterampilan abad 21 yang sangat dibutuhkan.

Rendahnya hasil survey PIRLS dan PISA tersebut dikarenakan kebiasaan membaca yang kurang sekali diminati oleh peserta didik di Indonesia. Hal tersebut pula yang menjadi salah satu penyebab mereka tidak memiliki budaya literasi yang baik. Salah satu budaya literasi yang sedikit dimiliki oleh peserta didik adalah budaya membaca. Berdasarkan survey awal yang dilakukan peneliti diperoleh data untuk budaya baca siswa terhadap 35 siswa kelas 4 SD diperoleh 21 orang siswa berada pada kategori rendah. Hal tersebut sesuai dengan pendapat Handayani \& Koeswanti (2020) yang menyatakan bahwa melalui observasi dan wawancara terdapat beberapa faktor yang menjadi penghambat minimnya minat membaca siswa diantaranya adalah minimnya media belajar yang beragam untuk menyampaikan materi pelajaran di kelas. Permasalahan lain yang menjadi hambatan dalam menarik minat membaca di sekolah tersebut yaitu ketersedian teks bacaan yang kurang bervariasi membuat siswa merasa kurang antusias untuk membaca. Oleh sebab itu diperlukan media belajar yang mampu menarik minat siswa dalam membaca.

Selain rendahnya budaya literasi membaca, aspek kemampuan budaya literasi menulis di negara ini juga sangat rendah. Data lanjutan hasil survey awal menunjukkan untuk kegiatan menulis secara aktif seperti menulis buku/catatan harian, latihan menulis didampingi orang tua hanya sebanyak 12 orang siswa dari 35 orang siswa saja yang sering melakukannya. Selebihnya kebanyakan siswa kesehariannya diisi untuk bermain HP. Banyak realita yang kita temui saat ini adalah minimnya budaya literasi khususnya minat membaca dan menulis pada peserta didik, hal ini bisa terjadi karena berbagai aspek salah satunya adalah tidak adanya pembiasaan atau budaya membaca yang tidak diterapkan oleh orang tua pada peserta didik sejak dini sehingga anak jaman sekarang terlihat asing dengan buku-buku. Anak-anak sekarang lebih banyak menghabiskan waktunya dengan gadget untuk bermain sosial media, game dan youtube (Kristianti et al., 2020).

Pada tahun 2015 dikeluarkanlah Permendikbud Nomor 23 Tahun 2015 yang menjadi dasar GLS (Gerakan Literasi Sekolah) yang merupakan awal mula suatu gerakan meliterasikan semua warga yang berada di ruang lingkup sekolah baik kepala sekolah, guru, penjaga, bahkan orang tua 
peserta didik. Mereka memiliki peran vital sebagai role model dan suri tauladan dalam kegiatan berliterasi bagi para peserta didik (Fauziah, 2016).

Tidak cukup sampai disana saja, pada tahun 2020 pihak Kementrian Pendidikan dan Kebudayaan mulai merencanakan penggunaan Asesmen Nasional untuk mengetes kemampuan literasi membaca, matematika dan sains yang rencananya akan mulai digunakan pada tahun 2021 mendatang. Alasan dilakukannya perubahan ini dikarenakan padatnya materi UN sehingga menyebabkan siswa dan guru cenderung hanya menguji penguasaan konten, bukan kompetensi nalar yang dimiliki oleh peserta didik. Selain itu, UN juga menjadi beban tersendiri bagi siswa, guru dan orang tua karena UN dianggap menjadi beban keberhasilan seorang siswa sebagai individu, bukan sebagai pemetaaan mutu sistem pendidikan nasional (Tim Tentor Anak Bangsa, 2020).

Ada 3 macam tes yang akan dilakukan di Asesmen Nasional, yaitu Asesmen Kompetensi Minimum (AKM), survey karakter dan survey belajar. AKM ini pada hakikatnya merupakan suatu proses pengumpulan data mengenai kemajuan dan hasil belajar siswa terhadap kompetensi (sikap, pengetahuan, dan keterampilan) yang terunjukkan secara komprehensif dalam rangka menyelesaikan masalah yang dihadapi menggunakan standar terendah (Marhaeni, 2020). Program tes AKM literasi membaca yang hendak dilakukan Kementrian Pendidikan dan Kebudayaan ini sudah menyesuaikan dari arahan PISA (2015) yang mendefinisikan bahwa literasi membaca merupakan "kemampuan untuk memahami, menggunakan, dan merefleksikan materi tertulis untuk mencapai tujuan pribadi, membentuk pengetahuan dan potensi pribadi, serta berpartisipasi dalam kegiatan sosial" dan telah digunakan hingga saat ini.

Lebih lanjut berdasarkan data hasil wawancara awal yang dilakukan peneliti terhadap salah seorang pendidik di SDN 2 Besakih pada tanggal 8 Maret 2021 diperoleh data dari pihak pendidik yang menujukkan bahwa adanya kesenjangan antara asesmen yang diharapkan oleh pihak pendidik dengan asesmen yang digunakan saat ini. Tidak hanya itu saja, peneliti juga menemukan bahwa belum pernah ada penggunaan tes AKM di SDN 2 Besakih ini. Padahal beberapa orang pendidik sudah ada yang mulai mempelajari mengenai AKM ini tetapi belum mampu untuk menerapkannya secara langsung. Berkaitan dengan tes AKM tersebut, menurut Pusat Asesmen Pembelajaran (2020) menyatakan bahwa pada AKM literasi membaca, terdapat tiga level indikator kognitif utama yang diujikan, yaitu (1) menemukan informasi (access and retrieve), (2) memahami (interpret and integrate), dan (3) mengevaluasi dan merefleksi (evaluate and reflect). Ketiga indikator utama ini lah mendasari berbagai pengembangan dan pembuatan soal AKM yang akan digunakan untuk asesmen nasional nanti. Namun sebelum dilaksanakannya secara langsung tes AKM literasi membaca tersebut, perlu bagi pihak sekolah untuk melatih agar setiap siswa mampu merasa terbiasa dahulu terhadap bentuk tes AKM ini. Pihak sekolah perlu melakukan beberapa latihan atau ujicoba tes AKM literasi membaca tersebut dengan bentuk soal yang mirip dengan panduan-panduan yang telah diberikan oleh pihak Kementrian Pendidikan dan Kebudayaan. Berdasarkan seluruh pemaparan diatas mengenai asesmen nasional dan tes asesmen kompetensi minimum yang memiliki hubungan dengan kemampuan literasi membaca menjadi alasan dilakukan penelitian pengembangan dengan judul "Pengembangan Instrumen Asesmen Kompetensi Minimum (AKM) Literasi Membaca Level 2 untuk Siswa Kelas 4 SD".

\section{METODE}

Metode yang digunakan dalam
penelitian ini adalah metode


pengembangan atau R\&D (Research and Developmet), merupakan metode yang digunakan untuk menghasilkan produk tertentu atau berorientasi pada produk (Sugiyono, 2019). Produk yang akan dikembangkan dalam penelitian ini adalah instrumen asesmen kompetensi minimum (AKM) yang dapat digunakan untuk mengukur kemampuan literasi membaca siswa kelas 4 SD. Terdapat tujuh langkah yang perlu ditempuh dalam mengembangkan tes hasil belajar menurut Mardapi (2008); dalam Widoyoko (2020). Ketujuh langkah tersebut terbagi menjadi 2 tahapan utama yaitu tahap perencaaan yang terdiri dari: (a) menyusun spesifikasi tes, (b) menulis soal tes, (c) menelaah soal tes, (d) memperbaiki tes, dan tahapan ujicoba yakni: (e) melakukan ujicoba tes, (f) menganalisis butir soal tes, (g) menafsirkan hasil tes.

Metode analisis data dalam penelitian ini terbagi menjadi 3 metode analisi. Analisis pertama untuk mengukur nilai validitas isi atau content validity (CV) dari instrumen yang dikembangkan menggunakan formula rumus Gregory berdasarkan penilaian dari 4 pakar. Ahli yang terlibat dalam penelitian ini yakni 2 orang judges dalam bidang pendidikan dan 2 orang judges dalam bidang psikologi tes. Adapun formula rumus yang ditemukan oleh Gregory untuk menghitung nilai CV adalah sebagai berikut.

$C V=\frac{A}{A+B+C+D+E+F+G+H+I+J+K+L+M+N+O+P}$

Keterangan:

$$
\begin{array}{rlr}
C V= & \text { validitas isi } \\
A= & \text { sel yang menunjukkan } \\
& \text { persetujuan yang valid antara } \\
& \text { keempat pakar } & \\
B-O= & \text { sel yang menunjukkan } \\
& \text { perbedaan pandangan antara } \\
& \text { keempat pakar } & \\
P= & \text { sel yang menunjukkan } \\
& \text { ketidaksetujuan } \\
& \text { keempat pakar antara } \\
\text { Kriteria valid atau tidaknya isi tiap }
\end{array}
$$
butir soal menggunakan acuan nilai kriteria interval yang dikemukakan oleh
Gregory (2000) dengan kriteria minimal validitas isinya tinggi atau pada interval $0,60<\mathrm{CV} \leq 0,79$. Selain mengukur nilai validitas isi dari instrumen AKM ini, penelitian ini juga mengukur nilai validitas empirisnya dengan menggunakan rumus perhitungan product moment dibantu menggunakan sofware SPSS for windows. Kriteria valid atau tidaknya tiap butir soal ditentukan dari perolehan nilai correlation person $(r)$ apabila nilai $r_{\text {hitung }}$ $>r_{\text {tabel. }}$. Proses perhitungan validitas empiris ini terbagi menjadi dua jenis ujicoba yang dilakukan yakni dari ujicoba dengan subyek terbatas sebanyak 17 orang siswa dan subyek secara luas yang diperoleh dari siswa kelas 4 SDN 2 Besakih dengan jumlah keseluruhan siswa kelas 4 berjumlah 35 orang. Adapun nilai $r_{\text {tabel }}$ untuk subyek terbatas adalah 0.482 , sedangkan nilai nilai $r_{\text {tabel }}$ untuk subyek luas adalah 0.361 . Selain mengukur nilai validitas, sebuah instrumen juga perlu diukur nilai reliabilitasnya. Adapun metode analisis yang digunakan untuk mengukur reliabilitas dari instrumen AKM ini adalah dengan menggunakan rumus Alpha Cronbach. Kriteria reliabilitas dari sebuah instrumen yang digunakan adalah kriteria dari Guilford (Koyan, 2012) yakni apabila soal yang dikembangkan memperoleh nilai minimal reliabilitasnya tinggi atau berada pada kriteria interval $0,60<\mathrm{x} \leq$ 0,80 .

\section{HASIL DAN PEMBAHSAN}

Penelitian ini berfokus utama
untuk menghasilkan produk berupa
instrumen asesmen kompetensi
minimum (AKM) literasi membaca level
2 dengan mengunakan bentuk penilaian
rating scale untuk setiap skor. Instrumen
AKM ini dikembangkan menggunakan
model yang diadaptasi dari model
Mardapi dalam Widoyoko (2020) yang
terdiri dari 7 langkah saja yang terbagi
menjadi 2 tahapan utama yaitu tahap
perencaaan terdiri dari: (a) menyusun
spesifikasi tes, (b) menulis soal tes, (c)
menelaah soal tes, (d) memperbaiki tes,


dan tahapan ujicoba yakni: (e) melakukan ujicoba tes, (f) menganalisis butir soal tes, (g) menafsirkan hasil tes.

Pada tahapan perencanaan, langkah pertama diawali dengan menyusun spesifikasi tes yang hendak dikembangkan oleh peneliti disini berisi uraian yang menunjukan keseluruhan karakteristik yang harus dimiliki oleh suatu tes. Penyusunan spesifikasi tes mencakup kegiatan: (a) menentukan tujuan tes (b) menyusun kisi-kisi tes (c) memilih bentuk tes, dan (d) menentukan panjang tes.

Langkah kedua dalam tahapan perencanaan ini adalah menulis butirbutir soal instrumen asesmen kompetensi minimum literasi membaca level 2. Banyaknya butir soal tes yang dibuat untuk setiap indikator minimal satu butir soal, yang disesuaikan dengan sub-sub indikator kemampuan literasi membaca yang diukur. Setiap butir soal disertai dengan rubrik penskoran. Soal yang dihasilkan dalam penelitian ini berupa tes tertulis dengan bentuk soal uraian, menjodohkan dan bentuk soal pilihan ganda kompleks sebanyak 30 butir soal untuk keseluruhan materi pembelajaran kelas 4 SD.

Langkah selanjutnya dari tahapan perencanaan ini adalah kegiatan penelaahan butir soal yang dilakukan oleh para ahli menggunakan teknik panel. Kegiatan ini bertujuan untuk memperoleh validitas isi dari para judges. Proses kegiatan penelaahan tes ini disertai dengan pemberian grand teori mengenai asesmen kompetensi minimum literasi membaca, kisi-kisi, kunci jawaban dan rubrik penilaian. Validitas isi dari instrumen AKM ini diperoleh dari penilaian 4 ahli (judges) yang hasilnya dihitung dan ditentukan menggunakan rumus yang ditemukan oleh Gregory. 4 ahli ini merupakan dosen ahli S2 Pascasarjana Universitas Pendidikan Ganesha. Selain memberikan penilaian terhadap produk instrumen, judges juga dapat memberikan saran dan komentar secara tertulis sebagai upaya perbaikan kualitas dari instrumen AKM yang dikembangkan.

Hasil dari setiap butir soal tes yang telah dianalisis oleh para judges tersebut baik untuk aspek penilaian, saran dan komentar kemudian direvisi dan diperbaiki oleh peneliti. Setelah seluruh butir-butir soal tes tersebut direvisi dan sudah dinyatakan valid, seluruh butir soal tersebut kemudian dipadukan menjadi satu paket tes yang siap untuk diujicobakan kepada siswa.

Kegiatan ujicoba instrumen merupakan langkah kelima dalam penelitian ini. Data hasil ujicoba instrumen kepada siswa tersebut berguna untuk menguji apakah instrumen yang dibuat telah memenuhi kriteria validitas berdasarkan analisis data empiris dan reliabilitas seluruh butir soal. Kegiatan ujicoba instrumen ini menggunakan seluruh subjek ujicoba agar memperoleh data nilai soal tes instrumen AKM literasi membaca dari siswa kelas 4 SD. Subyek yang digunakan dalam penelitian ini adalah peserta didik kelas 4 SDN 2 Besakih tahun ajaran 2020/2021 yang kini berada pada semester genap. Kelas 4 SDN 2 Besakih seluruhnya terdiri dari 35 orang peserta didik.

Insrumen yang telah selesai diujicobakan kepada seluruh subyek ujicoba kemudian dianalisis oleh peneliti. Proses pada tahapan ini peneliti menentukan perolehan skor setiap subyek uji coba pada setiap butir skor soal instrumen asesmen kompetensi minimum (AKM) literasi membaca. Kemudian setiap hasil skor perolehan peserta didik tersebut dimasukan kedalam data Ms. Excel yang selanjutnya akan dianalisis data validitas empiris dan reliabilitas seluruh butir soal dengan bantuan aplikasi software SPSS Statistic for windows versi 25.

Instrumen yang sudah melewati tahapan analisis validitas empiris dan reliabilitas melanjutkan ke tahapan terakhir ini yaitu menafsirkan hasil tes. Penafsiran hasil tes ini untuk menentukan apakah setiap butir soal instrumen asesmen kompetensi 
minimum (AKM) literasi membaca tersebut signifikan dengan ketentuan dalam melakukan analisis data validitas empiris dan hasil reliabilitas setiap butir soal instrumen tersebut. Apabila dalam tahapan ini hasil butir soal yang tidak valid, maka butir soal tersebut dinyatakan gugur dan tidak layak untuk digunakan.

Berdasarkan hasil penilaian dari judges instrumen asesmen kompetensi minimum (AKM) dikategorikan valid. Gregory (2000) menyatakan kriteria produk instrumen dinyatakan valid apabila nilai perolehan perhitungan content validity $(\mathrm{CV})>0,60$. Hasil perhitungan validitas isi dari tabulasi silang 4 judges menggunakan Rumus Gregory menghasilkan nilai validitas isi $(\mathrm{CV})=1$. Nilai validitas isi ini termasuk dalam kriteria "Validitas isi sangat tinggi" berdasarkan dari penentuan kriteria validitas isi yang dikemukan oleh Gregory. Diantara seluruh instrumen yang valid, ada beberapa catatan dari para ahli seperti pada nomor 2 misalnya yang memerlukan perubahan pergantian bentuk kalimat pertanyaan, hal tersebut ditunjukkan pada gambar berikut.

Pertanyaan 2 Layang-layang

\begin{tabular}{|l|l|}
\hline Jenjang & Level 2 (Kelas 4) \\
\hline Konten & Teks Informasi \\
\hline Konteks & Sosial-Budaya \\
\hline Kompetensi & Memahami (Interpret and integrate) \\
\hline Subkompetensi & $\begin{array}{l}\text { Menyusun inferensi, membuat koneksi dan prediksi baik teks } \\
\text { tunggal maupun teks jamak }\end{array}$ \\
\hline Rincian Kompetensi & $\begin{array}{l}\text { Menyusun inferensi (kesimpulan) terkait isi teks untuk } \\
\text { menentukan apakah suatu komentar/pertanyaan/ pernyataan } \\
\text { relevan dengan isi teks pada teks informasi. }\end{array}$ \\
\hline Bentuk Soal & Esai/Uraian \\
\hline
\end{tabular}

2. Apa penyebab bermain layang-layang menjadi sebuah tradisi di Bali?

Apa tidak sebaiknya pertanyaan no 2 ini sbb: Apa yang melatarbelakangi bermain layanglayang menjadi sebuah tradisi di Bali?

Gambar 2. Saran Bentuk Perubahan Butir Soal Nomor 2

Seperti yang terlihat pada gambar diatas, butir soal nomor 2 mengalami sedikit perubahan bentuk kalimat pertanyaan. Selain perubahan tersebut, ada beberapa catatan lain dari para judges yakni cerita yang digunakan sebaiknya menyesuaikan dengan kemampuan membaca siswa kelas 4, dan juga perlunya perubahan beberapa kalimat yang masih berbentuk kalimat baku. Berbagai saran judges tersebut sejalan dengan pendapat Zahrudin et al., (2021) yang menyatakan bahwa dalam literasi membaca terdapat empat aspek kajian utama yang perlu diperhatikan, yaitu: (1) keterampilan membaca; (2) penerapan, pelatihan, dan penetapan bacaan; (3) proses membaca; dan (4) teks yang digunakan dalam membaca.

Kegiatan analisis data validitas empiris ini terpisahkan menjadi 2 bagian, yakni analisis data subyek secara terbatas yang berjumlah 17 orang dan analisis data subyek secara luas dengan total 35 orang. Adapun data hasil analisis correlation person menggunakan sofware SPSS for windows versi 25 dapat dilihat pada tabel berikut. 
Tabel 1. Hasil Perhitungan Uji Validitas Empiris menggunakan SPSS

\begin{tabular}{|c|c|c|c|c|c|}
\hline \multirow{2}{*}{ No. Butir Soal } & \multicolumn{2}{|c|}{ Subyek terbatas } & \multicolumn{2}{|c|}{ Subyek luas } & \multirow{2}{*}{ Ket } \\
\hline & $r$ hit & taraf sig. & $r$ hit & taraf sig. & \\
\hline 1 & 0.831 & 0.000 & 0.890 & 0.001 & Valid \\
\hline 2 & 0.528 & 0.030 & 0.606 & 0.001 & Valid \\
\hline 3 & 0.653 & 0.004 & 0.714 & 0.001 & Valid \\
\hline 4 & 0.690 & 0.002 & 0.631 & 0.001 & Valid \\
\hline 5 & 0.825 & 0.000 & 0.860 & 0.001 & Valid \\
\hline 6 & 0.684 & 0.002 & 0.661 & 0.001 & Valid \\
\hline 7 & 0.671 & 0.003 & 0.693 & 0.001 & Valid \\
\hline 8 & 0.883 & 0.000 & 0.896 & 0.001 & Valid \\
\hline 9 & 0.741 & 0.001 & 0.747 & 0.001 & Valid \\
\hline 10 & 0.694 & 0.002 & 0.754 & 0.001 & Valid \\
\hline 11 & 0.490 & 0.046 & 0.439 & 0.001 & Valid \\
\hline 12 & 0.740 & 0.001 & 0.773 & 0.001 & Valid \\
\hline 13 & 0.837 & 0.000 & 0.879 & 0.001 & Valid \\
\hline 14 & 0.495 & 0.043 & 0.562 & 0.001 & Valid \\
\hline 15 & 0.671 & 0.003 & 0.579 & 0.001 & Valid \\
\hline 16 & 0.787 & 0.000 & 0.853 & 0.001 & Valid \\
\hline 17 & 0.750 & 0.001 & 0.742 & 0.001 & Valid \\
\hline 18 & 0.616 & 0.009 & 0.714 & 0.001 & Valid \\
\hline 19 & 0.723 & 0.001 & 0.762 & 0.001 & Valid \\
\hline 20 & 0.847 & 0.000 & 0.895 & 0.001 & Valid \\
\hline 21 & 0.668 & 0.003 & 0.764 & 0.001 & Valid \\
\hline 22 & 0.851 & 0.000 & 0.861 & 0.001 & Valid \\
\hline 23 & 0.767 & 0.000 & 0.827 & 0.001 & Valid \\
\hline 24 & 0.755 & 0.000 & 0.816 & 0.001 & Valid \\
\hline 25 & 0.757 & 0.000 & 0.751 & 0.001 & Valid \\
\hline 26 & 0.633 & 0.006 & 0.631 & 0.001 & Valid \\
\hline 27 & 0.729 & 0.001 & 0.697 & 0.001 & Valid \\
\hline 28 & 0.659 & 0.004 & 0.673 & 0.001 & Valid \\
\hline 29 & 0.718 & 0.001 & 0.743 & 0.001 & Valid \\
\hline 30 & 0.795 & 0.000 & 0.839 & 0.001 & Valid \\
\hline
\end{tabular}

Berdasarkan data pada tabel diatas dapat kita lihat hasil analisis correlation person untuk nilai $r_{\text {hitung }}$ secara keseluruhan dari 30 butir soal $>$ $r_{\text {tabel }}$ untuk subyek 17 nilai $r_{\text {tabel }}$ sebesar 0.482 dengan perolehan nilai terkecil 0.490 dan yang terbesar 0.883 . Selain nilai correlation person tersebut, seluruh nilai signifikansi yang ditunjukan oleh output analisis software SPSS terhadap 30 butir soal $<0.05$. Sehingga dapat kita tarik kesimpulan bahwa seluruh soal instrumen asesmen kompetensi minimum (AKM) literasi membaca level 2 ini valid dari segi ujicoba subyek secara terbatas.

Selain hasil ujicoba subyek secara terbatas, hasil analisis ujicoba subyek secara luas menggunakan software SPSS for windows versi 25 juga menunjukkan hasil bahwa nilai correlation person untuk instrumen asesmen kompetensi minimum (AKM) literasi membaca level 2 dari keseluruhan 30 butir soal memperoleh nilai $r_{\text {hitung }}>r_{\text {tabel }}$ untuk subyek 35 orang 
nilai $r_{\text {tabel }}$ sebesar 0.361 dengan perolehan nilai terkecil 0.439 dan nilia terbesar 0.896. Selain ditinjau dari nilai correlation person nya, seluruh 30 butir soal instrumen AKM literasi membaca memperoleh nilai signifikansi $<0.05$ yang ditunjukan oleh output analisis software SPSS.

Sebuah Instrumen dikatakan valid apabila instrumen tersebut mampu secara tepat mengukur apa yang hendak diukur. Dengan kata lain validitas berkaitan dengan "ketepatan" dengan alat ukur. Instrumen yang valid akan menghasilkan data yang valid pula. Bisa juga dikatakan bahwa jika data yang dihasilkan dari sebuah instrumen valid, maka instrumen itu juga valid (Widoyoko, 2020). Pernyataan tersebut selalan dengan pendapat Sugiyono (2019) yang menyatakan bahwa sebuah instrumen yang valid harus memiliki nilai validitas internal dan validitas eksternal. Validitas internal instrumen harus memenuhi validitas konstruk dan validitas isi, sedangkan untuk validitas eksternal adalah nilai empiris dari instrumen yang apabila digunakan dimana-mana akan memperoleh hasil data yang valid.

Instrumen yang sudah dianalisis dari aspek validitas isi dan empirisnya kemudian perlu diketahui seberapa besar nilai reliabilitasnya. Perhitungan dilakukan menggunakan sofware SPSS versi 25 memperoleh hasil nilai reliabilitas dengan menggunakan rumus Alpha Cronbach ditunjukkan pada tabel dibawah ini.

Tabel 2. Hasil Perhitungan Reliabilitas dengan Alpha Cronbach

\begin{tabular}{cr}
\hline \multicolumn{3}{c}{ Reliability Statistics } \\
\hline $\begin{array}{c}\text { Cronbach's } \\
\text { Alpha }\end{array}$ & N of Items \\
\hline, 971 & 30 \\
\hline
\end{tabular}

Berdasarkan hasil analisis uji reliabilitas berbantu software SPSS versi 25 diperoleh tingkat reliabilitas dari instrumen AKM literasi membaca sebesar 0,971. Data nilai hasil perhitungan ini menunjukkan bahwa instrumen asesmen kompetensi minimum (AKM) literasi membaca ini dinyatakan reliabel karena memberikan nilai Alpha Cronbach $(\alpha)>0.60$ dan data hasil analisis tersebut termasuk dalam klasifikasi "Sangat tinggi". Perolehan nilai reliabilitas yang tinggi ini menunjukkan bahwa instrumen AKM ini memiliki koefisien internal konsistensi tiap butir soal yang berjenis sama memiliki nilai kepercayaan dalam pengukuruannya bersifat ajeg (Sugiyono, 2019). Hal tersebut sesuai dengan pendapat Otaya et al., (2020) yang menyatakan bahwa sebuah instrumen yang handal akan memberikan hasil pengukuran yang stabil dan konsisten.

Pengembangan instrumen AKM literasi membaca ini meliputi tiga jenis level kognitif. Pada level kognitif menemukan informasi: (1) mengakses dan mencari informasi dalam teks; (2) mencari dan memilih informasi yang relevan. Pada level kognitif memahami: (1) memahami teks secara literal; (2) Menyusun inferensi, membuat koneksi dan prediksi baik teks tunggal maupun teks jamak. Pada level kognitif mengevaluasi dan merefleksi: (1) Menilai kualitas dan kredibilitas konten pada teks informasi tunggal maupun jamak; (2) Menilai format penyajian dalam teks; (3) Merefleksi isi wacana untuk pengambilan keputusan, menetapkan pilihan, dan mengaitkan isi teks terhadap pengalaman pribadi.

Sejalan dengan pendapat Ibda (2018) era revolusi industri 4.0 tidak bisa ditelaah hanya berdasarkan berbagai aspek tantangan dan perubahannya saja. Banyaknya tantangan yang ada tentu memiliki peluangnya tersendiri. Berbagai tantangan itu akan mampu dilewati apabila guru mampu mengimbangi dengan kemampuan penggunaan teknologi. Tidak cukup sampai disana saja, penguatan berbagai jenis literasi baru dapat menjadi pelengkap bagi literasi lama. Literasi bisa memperkuat pemahaman guru dan peserta didik. Guru wajib mempelajari 
berbagai jenis literasi baru (data, teknologi, SDM/humanisme) serta mampu membekali diri dengan kompetensi literasi yang berpusat pada pilar literasi pendidikan abad 21 (baca, tulis, arsip).

Penelitian ini juga sejalan dengan penelitian yang dilakukan oleh Nurindanasari et al., (2020) melalui pengembangan bahan ajar Instrumen Authenthic Assessment pada aspek literasi membaca kelas $\mathrm{V}$ di SDN PLAOSAN 03 diperoleh hasil bahan ajar instrument authenthic assessment yang termasuk dalam kategori sangat layak atau sangat valid yang ditinilai oleh ahli assessmet dan Bahasa. Ahli praktisi dan pengamat berada pada klasifikasi sangat layak atau valid serta praktis. Jadi bahan ajar Instrumen Authenthic Assessment pada aspek literasi membaca kelas $\mathrm{V}$ dapat digunakan dilapangan.

Penelitian

pengembangan instrumen ini juga sejalan dengan penelitian yang dilakukan oleh Murti et al., (2021) validitas isi instrumen yang dikembangkan berada pada kategori sangat layak, baik pada ranah materi, konstruksi, maupun bahasa. Hasil uji validitas empiris yang terdiri dari tingkat kesukaran soal, daya pembeda, reliabilitas, dan validitas item, memperoleh sebanyak 9 dari 16 butir soal dinyatakan layak secara empiris.

Berdasarakan seluruh pemaparan diatas yang membuktikan dan menunjukkan data bahwa selain seluruh 30 butir soal instrumen asesmen kompetensi minimum (AKM) literasi membaca level 2 tersebut valid baik secara isi maupun secara empiris. Seluruh 30 butir soal instrumen asesmen kompetensi minimum (AKM) literasi membaca level 2 tersebut juga reliabel dan layak untuk digunakan pada siswa jenjang sekolah dasar kelas 4 .

\section{PENUTUP}

Secara umum kesimpulan dalam penelitian pengembangan ini berfokus untuk menghasilkan instrumen AKM literasi membaca level 2 berupa soal uraian, menjodohkan dan pilihan ganda kompleks dengan jumlah sebanyak 30 butir soal. Seluruh 30 butir soal tersebut dianalisis untuk mengetahui nilai uji validitas isi untuk instrumen AKM literasi membaca level 2 untuk siswa kelas 4 SD menggunakan rumus Gregory 4 ahli. Berdasarkan hasil perhitungan Gregory diperoleh hasil nilai CV sebesar 1 termasuk dalam kategori validitas isi sangat tinggi, sehingga didapatkan 0 butir instrumen yang tidak valid dan 30 instrumen yang valid dan layak untuk diujicobakan.

Selain menganalisis nilai dari validitas isi dari seluruh butir soal tersebut, sertiap butir soal juga dianalisis untuk mengetahui nilai validitas empirisnya dengan pelaksanaan 2 jenis analisis yakni menggunakan jumlah subyek secara terbatas dan secara luas. Hasil analisis uji validitas empiris baik untuk subyek secara terbatas maupun luas menunjukkan nilai $r_{\text {hitung }}>r_{\text {tabel }}$ untuk keseluruhan 30 butir soalnya. Sehingga dapat dikatakan bahwa dari segi empiris instrumen asesmen kompetensi minimum literasi membaca ini dikatakan sudah valid. Analisis terakhir yang dilakukan adalah perhitungan reliabilitas instrumen yang datanya diperoleh dari hasil jawaban siswa. Adapun perolehan nilai reliabilitas untuk instrumen AKM literasi membaca level 2 ini sebesar 0.971 yang termasuk dalam kategori reliabilitas sangat tinggi. $\mathrm{Hal}$ ini menyatakan bahwa instrumen asesmen kompetensi minimum literasi membaca level 2 ini baik secara validitas isi maupun validitas empiris dan secara konsistennya memperoleh kategori nilai yang sangat tinggi dan sudah layak untuk dipergunakan secara langsung untuk setiap peserta didik kelas 4 di Sekolah Dasar.

Berdasarkan simpulan yang telah dikemukakan diatas, maka peneliti merekomendasikan beberapa hal sebagai berikut: (1) bagi pemerintah sebaiknya lebih banyak melaksanakan kegiatan seminar untuk para pendidik agar mampu meningkatkan kemampuan 
abad 21 yakni kemampuan literasi untuk siswa kelas 4 SD, (2) bagi pendidik, hasil penelitian ini diharapkan dapat menjadi pedoman dalam merancang pengembangan instrumen asesmen kompetensi minimum literasi membaca yang serupa sehingga semakin banyak instrumen yang dapat digunakan oleh pendidik sebagai latihan untuk siswanya, (3) Terakhir melalui penelitian pengembangan ini diharapkan mampu memberikan motivasi bagi setiap pembacanya terutamanya yang berkecimpung dalam bidang pendidikan untuk lebih meningkatkan bentuk asesmen guna meningkatkan kualitas dari sumber daya manusia di negara ini. Serta mampu menujukkan efektivitas dari instrumen asesmen kompetensi minimum ini.

\section{DAFTAR RUJUKAN}

Fauziah, R. (2016). Penerapan Whole Language Untuk Meningkatkan Keterampilan Membaca Pemahaman Siswa Sekolah Dasar. Jurnal Pendidikan Guru Sekolah, 1(1), 12-24. https://doi.org/10.17509/jpgsd.v1i1. 9059

Gregory, R. J. (2000). Psychological Testing: History, Principles, and Applications. Boston: Allyn and Bacon.

Handayani, P., \& Koeswanti, H. D. (2020). Pengembangan Media Komik Untuk Meningkatkan Minat Membaca Siswa Sekolah Dasar. Jurnal Basicedu, 4(2), 396-401. https://doi.org/10.31004/basicedu.v $4 \mathrm{i} 2.365$

Harlina, \& Wardarita, R. (2020). Peran Pembelajaran Bahasa dalam Pembentukan Karakter Siswa Sekolah Dasar. Jurnal Bindo Sastra, 4(1), 63-68. https://doi.org/10.32502/jbs.v4i1.23 32

Ibda, H. (2018). Penguatan Literasi Baru pada Guru Madrasah Ibtidaiyah dalam Menjawab Tantangan Era
Revolusi Industri 4.0. Journal of Research and Thought of Islamic Education, 1(1), 1-19.

Indriyani, V., Zaim, M., Atmazaki, \& Ramadhan, S. (2019). Literasi Baca Tulis dan Inovasi Kurikulum Bahasa. Jurnal Keilmuan Bahasa, Sastra, Dan Pengajarannya, 5(1), 108-118.

Koyan, I. W. (2012). Statistik Pendidikan, Teknik Analisis Data Kuantitatif. Singaraja: Universitas Pendidikan Ganesha.

Kristianti, T. L., Yusuf, Y., \& Handini, O. (2020). Analisis Penerapan Gerakan Literasi Sekolah Pada Pembelajaran Tematik Integratif. Jurnal Sinektik, 3(2), 197-210. https://doi.org/10.36456/abadimas. v5.i01.a3634

Lamada, M., Rahman, E. S., \& Herawati. (2019). Analisis Kemampuan Literasi Siswa SMK Negara Di Kota Makassar. Jurnal Media Komunikasi Pendikan Teknologi Dan Kejuruan, 6(1), 3542.

https://doi.org/10.26858/mekom.v6i 1.12000

Marhaeni, A. A. I. N. (2020). Asesmen Kompetensi Minimum (AKM). WEBINAR Universitas Pendidikan Ganesha.

Murti, Wisnu, W., \& Sunarti, T. (2021). Pengembangan Instrumen Tes Literasi Sains Berbasis Kearifan Lokal di Trenggalek. ORBITA. Jurnal Hasil Kajian, Inovasi, Dan Aplikasi Pendidikan Fisika, 7(1), 33-43.

https://doi.org/10.31764/orbita.v7i1 .4386

National Center Education Statistics. (2013). Highlights From PIRLS 2011 (p. 60). U.S. Departement Of Education.

https://nces.ed.gov/pubs2013/2013 010rev.pdf

Nurindanasari, D. A., Setiawan, D. A., \& 
Yuniasih,

N.

(2020).

Pengembangan

Kependidikan,

Pengembangan

Instrument 12(1), 83-91.

Authentic Assessment Pada Aspek

Literasi Membaca di SDN 03

Plaosan Kabupaten Malang.

Seminar Nasional PGSD

UNIKAMA, 4, 123-130.

OECD. (2019). PISA 2018 Results: Country Note Indonesia. OECD Publishing.

https://www.oecd.org/pisa/publicati ons/PISA2018_CN_IDN.pdf

Otaya, L. G., Kartowagiran, B., \& Retnawati, H. (2020). The Construct Validity And Reliability Of The Lesson Plan Assessment Instrument In Primary Schools. Jurnal Prima Edukasia, 8(2), 126134.

PISA. (2015). PISA 2015 Draft Reading Literacy Framework. OECD Publishing.

https://www.oecd.org/pisa/pisaprod ucts/Draft\%20PISA\%202015\%20R eading\%20Framework\%20.pdf

Pusat Asesmen Pembelajaran. (2020). DESAIN PENGEMBANGAN SOAL $A K M$. Kementerian Pendidikan dan Kebudayaan.

https://drive.google.com/file/d/1vVw 8-RAXXbG4a-NSEusdz5BS3ueDiN/view

Sugiyono. (2019). Metode Penelitian dan Pengembangan (Research and Development/ R\&D). Bandung: Alfabeta CV.

Tim Tentor Anak Bangsa. (2020). BANK SOAL AKM \& SK SD/MI. Yogyakarta: ARRUZZ MEDIA.

Widoyoko, E. P. (2020). Teknik Penyusunan Instrumen Penelitian. Yogyakarta: PUSTAKA BELAJAR.

Zahrudin, M., Ismail, S., \& Zakiah, Q. Y. (2021). Policy Analysis Of Implementation of Minimum Competency Assessment as an Effort to Improve Reading Literacy of Students in Schools. Jurnal Kajian, Penelitian Dan 